\title{
ANALISIS STRUKTUR TEROWONGAN PENGELAK PADA BENDUNGAN KUALU KABUPATEN TOBA SAMOSIR PROVINSI SUMATRA UTARA
}

\author{
Afan Allail Rofikha ${ }^{1}$, Suwanto Marsudi ${ }^{2}$, Evi Nur Cahya ${ }^{2}$ \\ ${ }^{1}$ Mahasiswa Program Sarjana Teknik Jurusan Pengairan Universitas Brawijaya \\ ${ }^{2}$ Dosen Teknik Pengairan Fakultas Teknik Universitas Brawijaya \\ Jalan MT. Haryono 167 Malang 65145 Indonesia \\ Email: afanallail31@gmail.com
}

\begin{abstract}
ABSTRAK : Bangunan pengelak terdiri dari terowongan pengelak dan bendungan pengelak. Bangunan yang harus dibangun pada awal konstruksi sebuah bendungan, memiliki fungsi untuk mengalihkan aliran air sungai selama periode pembangunan bendungan. Perencanaan terowongan pengelak Bendungan Kualu didesain menggunakan bentuk tapal kuda shape $F$, hulu terowongan berada di kedalaman 41,625 m dan elevasi dasar hulu +695,5 m. Dalam studi ini dilakukan penelusuran banjir dengan debit banjir kala ulang 25 th sebesar $709,331 \mathrm{~m}^{3} / \mathrm{dt}$ dan didapatkan diameter terowongan $9 \mathrm{~m}$, kemudian direncanakan cofferdam setinggi $15 \mathrm{~m}$. Dilakukan perhitungan pembebanan dan dihitung 4 kombinasi pembebanan yaitu kondisi setelah dibangun, kondisi setelah dibangun (gempa), kondisi setelah beroperasi, dan kondisi setelah beroperasi (gempa). Dari hasil kombinasi pembebanan dilakukan perhitungan momen menggunakan metode Beggs dan metode Staad Pro. Dilakukan analisa pemilihan momen maksimum yang kemudian digunakan untuk perhitungan penulangan pada terowongan. Setelah melakukan analisis, dapat diketahui bahwa terjadi perbedaan letak titik momen maksimum, hal ini diakibatkan pada metode Beggs tumpuan diasumsikan sebagai gaya vertikal atau beban vertikal.
\end{abstract}

Kata kunci: Terowongan Pengelak, kombinasi pembebanan, momen maksimum, penulangan, Analisis Struktur.

\begin{abstract}
Diversion structure consists of diversion tunnel and Cofferdam. These two contructions should built in the early construction of the dam, have function to divert the river flow during the period of dam construction. The plans of Kualu dam diversion tunnel designed using horseshoe shape $F$, upstream of the tunnel at a depth of $41.625 \mathrm{~m}$ and upstream elevation $+695.5 \mathrm{~m}$. In this study there was flood routing with Q25th which is $709,331 \mathrm{~m}^{3} / \mathrm{s}$ and obtained using $9 \mathrm{~m}$ diameter, then a cofferdam is planned to build as high as $15 \mathrm{~m}$. Based on the calculation of loading and calculated four load combinations, they are : after contruction condition, after contruction under earthquake condition, at the operation time condition, and at the operation time under earthquake condition. From the results of the load combinations, the structure was analyzed using Beggs method and Staad Pro method. These two methods were used to figure the maximum moment of the structure and to determine the needed reinforcement in the tunnel construction. After the analysis, it is noticed that there is a difference position of the maximum moment, this is caused by the support in the Beggs method assumed to be a vertical loads.
\end{abstract}

Keywords: Diversion Tunnel, Load Combination, Maximum Moment, Reinforcement, Structural Analysis. 
Bendungan merupakan sebuah konstruksi yang didesain agar kuat untuk menahan dan menyimpan air, sehingga air dapat digunakan sesuai dengan keperluan. Permasalahan terhadap penyediaan berbagai kebutuhan air dapat terpenuhi dengan dibangunnya sebuah bendungan. Permasalahan yang dapat diatasi seperti penyediaan kebutuhan air untuk irigasi dan kebutuhan air baku. Selain itu dengan memanfaatkan energi potensial dan kinetik yang dimiliki air akan dapat menghasilkan energi listrik, maka untuk menambah pasokan listrik dapat dilakukan dengan membangun PLTA pada sebuah bendungan.

Pemerintah saat ini sedang sangat gencar memperbaiki ketertinggalan Indonesia di bidang infrastruktur. Ketertinggalan infrastruktur juga mengakibatkan pembangunan ekonomi nasional yang tidak merata. Oleh karena itu selain pembangunan jalan, jembatan, kereta, pemerintah juga membangun infrastruktur seperti waduk dan bendungan. Untuk meningkatkan produksi pertanian, penyediaan air baku dan penyediaan listrik, pemerintah saat ini menargetkan penyelesaiaan pembangunan 49 bendungan.

Bendungan Kualu adalah sebuah bendungan yang akan dibangun di Kabupaten Toba Samosir Provinsi Sumatra Utara. Dalam proses pembangunan Bendungan Kualu memerlukan sebuah terowongan pengelak yang berfungsi untuk mengalihkan aliran sungai selama proses pembangunan bendungan berlangsung. Terowongan pengelak sangat penting dan wajib untuk dibangun untuk mendukung pelaksanaan konstruksi bendungan agar berjalan dengan lancar. Oleh karena itu, perlu dilakukan analisis struktur agar terowongan yang akan dibangun kuat menahan beban yang ada dan dapat bekerja sesuai dengan fungsinya.

\section{METODOLOGI PENELITIAN \\ Lokasi Studi}

Lokasi bendungan terletak di Sungai Kualu terletak pada koordinat UTM zona 47, $543.733 \mathrm{~m}$ T dan $252.296 \mathrm{~m}$ U di Kecamatan Nassau Kabupaten Toba Samosir, Sumatra Utara. Kecamatan Nassau berada pada ketinggian 300 meter hingga 1.650 meter di atas permukaan laut. Sungai kualu memiliki Panjang $24,79 \mathrm{~km}$ dan luas DAS 465,44 km².



Gambar 1 Lokasi Daerah Studi

Sumber : Laporan Faktual Penyelidikan Tanah Bendungan Kualu (2018)

\section{Data Penunjang}

Dalam perencanaan terowongan pengelak, data-data yang dibutuhkan adalah sebagai berikut:

1. Debit banjir rancangan Bendungan Kualu.

2. Peta kontur dan denah bendungan.

3. Data bor log.

4. Peta lokasi bor log pada terowongan pengelak.

5. Muka air tanah pada terowongan pengelak

\section{Tahap Penyelesaian Studi}

1. Menggunakan debit banjir kala ulang 25 th $\left(\mathrm{Q}_{25 \text { th }}\right)$ untuk perhitungan perencanaan terowongan pengelak.

2. Melakukan perhitungan penelusuran banjir. Dimulai dengan melakukan analisis hidrolika pada terowongan. Perhitungan ini terbagi menjadi tiga kondisi yaitu kondisi aliran bebas, aliran transisi, dan aliran tertekan.

3. Membuat desain terowongan pengelak.

4. Melakukan analisis pembebanan pada terowongan. Kondisi pembebanan yang akan dilakukan dalam perencanaan adalah sebagai berikut :

- Tekanan batuan vertikal

- Tekanan batuan horizontal

- Tekanan air vertikal

- Tekanan air horizontal

- Beban akibat berat sendiri

- Tekanan air dalam terowongan

- Tekanan uplift

5. Perhitungan momen, normal dan lintang.

6. Perhitungan penulangan pada terowongan. 
HASIL DAN PEMBAHASAN

Analisa Hidrolika

\section{Perhitungan Penelusuran Banjir}

Digunakan terowongan pengelak shape $\mathrm{F}$ dengan melakukan beberapa percobaan diameter terowongan mulai dari $6 \mathrm{~m}, 7 \mathrm{~m}, 8 \mathrm{~m}$, $9 \mathrm{~m}$ dan $10 \mathrm{~m}$. Terowongan didesain sepanjang $197 \mathrm{~m}$ dengan kemiringan dasar saluran 0,018.



Gambar 2 Sketsa Terowongan Pengelak Shape $F$

Sumber: United States Departement of the Interior (1987)

Pertama dilakukan perhitungan kondisi aliran. Digunakan dua jenis kondisi aliran yaitu kondisi bebas dan kondisi tertekan. beberapa parameter yang dibutuhkan dalam perhitungan aliran bebas dan tertekan dilakukan dengan interpolasi pada tabel yang telah disediakan di buku design of small dam yaitu telah tersebut pada tabel Velocity head and discharge at critical depths dan Uniform Flow in Horseshoe Sections Flowing party full.

1. Perhitungan Aliran Bebas $(\mathrm{h}<1,2 \mathrm{D})$

Untuk menentukan kecepatan aliran dalam saluran pengelak digunakan rumus Manning (Chow,1992):

$\mathrm{V}=\frac{1}{\mathrm{n}} \mathrm{R}^{2 / 3} \mathrm{~S}^{1 / 2}$

$\mathrm{Q}=\mathrm{A} . \mathrm{V}$

Dimana :

$\mathrm{Q}=$ debit yang mengalir pada kedalaman tertentu $\left(\mathrm{m}^{3} / \mathrm{det}\right)$

$\mathrm{R}=$ jari-jari hidrolis $=\mathrm{A} / \mathrm{P}(\mathrm{m})$

$\mathrm{A}=$ luas penampang basah $\left(\mathrm{m}^{2}\right)$

$\mathrm{P}=$ keliling basah $(\mathrm{m})$

$\mathrm{D}=$ diameter saluran $(\mathrm{m})$

$\mathrm{S}=$ kemiringan saluran

$\mathrm{n}=$ koefisien kekasaran Manning $(0,014)$ beberapa parameter yang dibutuhkan dalam perhitungan aliran bebas dan tertekan dilakukan dengan interpolasi pada tabel yang telah disediakan di buku design of small dam yaitu telah tersebut pada tabel 2.2 Velocity head and discharge at critical depths dan 2.3 Uniform Flow in Horseshoe Sections Flowing party full.

Sedangkan jika slope saluran termasuk dalam kategori terjal (steep slope), maka akan terjadi aliran super kritis, sehingga rumus aliran seragam Manning tidak berlaku. Dengan demikian karakteristik alirannya dapat diasumsikan sebagai aliran kritis. Perhitungan kapasitas aliran dengan titik kontrol hidrolis di inlet terowongan dihitung dengan rumus aliran kritis sebagai berikut :

$$
\begin{aligned}
\mathrm{Y}_{\mathrm{c}} & =2 / 3 \cdot \mathrm{H} \ldots \\
\mathrm{V}_{\mathrm{c}} & =\left(\mathrm{g} \mathrm{\textrm {Y } _ { \mathrm { c } }}\right)^{1 / 2} \ldots \\
\mathrm{A}_{\mathrm{c}} & =\mathrm{B} \cdot \mathrm{Y}_{\mathrm{c}} \ldots \\
\mathrm{Q}_{\mathrm{c}} & =\mathrm{A}_{\mathrm{c}} \cdot \mathrm{V}_{\mathrm{c}} \ldots \ldots
\end{aligned}
$$

\section{Dimana :}

$$
\begin{array}{lll}
\mathrm{Q}_{\mathrm{c}} & =\text { debit aliran kritis }\left(\mathrm{m}^{3} / \mathrm{det}\right) \\
\mathrm{V}_{\mathrm{c}} & =\text { kecepatan aliran kritis }(\mathrm{m} / \mathrm{det}) \\
\mathrm{A}_{\mathrm{c}} & =\text { luas penampang basah }\left(\mathrm{m}^{2}\right) \\
\mathrm{Y}_{\mathrm{c}} & =\text { kedalaman aliran kritis }(\mathrm{m} / \mathrm{det})
\end{array}
$$

\section{Perhitungan Aliran Tertekan $(\mathrm{h}>1,5 \mathrm{D})$}

Tahapan dalam perhitungan hidrolika aliran tertekan adalah sebagai berikut:

1. Nilai $\mathrm{A}$, dan $\mathrm{R}$ didapat dengan interpolasi pada tabel 4.1 dan 4

2. Menghitung koefisien hambatan

- Koefisien pada outlet (Co)

$$
\mathrm{Co}=1
$$

- Koefisien gesekan $(\mathrm{Cf})$

$$
\mathrm{Cv}=\mathrm{n}^{2} . \mathrm{L} . / \mathrm{R}^{4 / 3}
$$

- Koefisien inlet (Ci)

$$
\mathrm{Ci}=0,5
$$

3. Menghitung nilai $v$

$$
\mathrm{V}=\sqrt{\frac{2 \cdot g \cdot\left(\text { elevasi muka air-elevasi inlet }-\frac{D}{2}+L \cdot \sin \theta\right)}{\left(1+\sum c\right)}}
$$

4. Menghitung nilai $Q$, menggunakan rumus kontinuitas

$\mathrm{Q}=\mathrm{v} . \mathrm{A}$

\section{Analisa Pemilihan Diameter Terowongan Pengelak}

Analisa yang dilakukan setelah melakukan perhitungan penelusuran banjir menggunakan beberapa alternatif dimensi dari 
terowongan pengelak. Dari hasil penelusuran banjir didapatkan:

Tabel 1Rekapitulasi Hasil Penelusuran Banjir

\begin{tabular}{|l|l|l|l|l|}
\hline No & $\begin{array}{c}\text { Diameter } \\
\text { Terowongan } \\
\text { (m) }\end{array}$ & $\begin{array}{c}\mathrm{H} \\
\text { maks } \\
(\mathrm{m})\end{array}$ & elevasi & keterangan \\
\hline 1 & 6 & - & - & Diameter terlalu kecil \\
\hline 2 & 7 & - & - & Diameter terlalu kecil \\
\hline 3 & 8 & 23,431 & 718,931 & Diameter dapat digunakan \\
\hline 4 & 9 & 13,600 & 709,100 & Diameter dapat digunakan \\
\hline 5 & 10 & 11,266 & 706,766 & Diameter dapat digunakan \\
\hline
\end{tabular}

Dari hasil penelusuran banjir dengan menggunakan diameter $6 \mathrm{mdan} 7 \mathrm{~m}$ diperoleh kapasitas tampungan waduk hingga elevasi tertinggi (+732) tidak dapat menampung debit banjir rancangan $(\mathrm{Q} 25$ th) sehingga diameter ini tidak dapat digunakan karena diameter terowongan terlalu kecil.

Pada tabel 1 menjelaskan tinggi air maksimum pada tampungan dengan diameter tertentu. Dari hasil analisa dipilih digunakan diameter terowongan pengelak $9 \mathrm{~m}$ dengan alasan:

- Terowongan sepanjang $197 \mathrm{~m}$ dengan material dari beton bertulang, akan lebih efisien dari segi biaya jika menggunakan diameter $9 \mathrm{~m}$ dikarenakan volume beton akan lebih mahal jika dibandingkan dengan material urugan.

- Dari segi h air maksimum yang diperoleh akan menghasilkan tinggi cofferdam yang tidak terlalu tinggi (kurang dari $40 \%$ dari tinggi bendungan).

grafik rating curve dan penelusuran banjir dengan menggunakan diameter $9 \mathrm{~m}$ dapat dilihat pada gambar 3 dan gambar 4 .

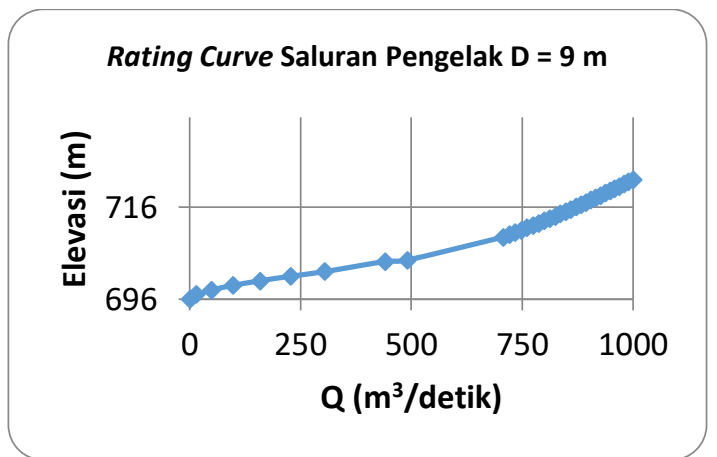

Gambar 3 Grafik Perhitungan Rating Curve Saluran Pengelak (Diameter Terowongan Pengelak $9 \mathrm{~m}$ )

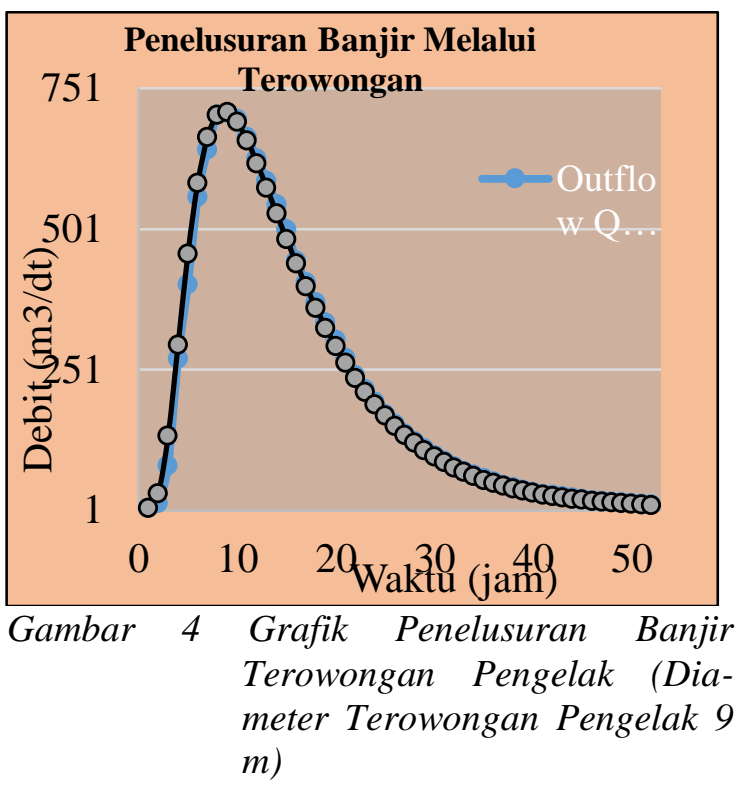

\section{Perhitungan Tinggi Cofferdam}

Perhitungan tinggi cofferdam didasarkan pada elevasi permukaan air yang terdapat di depan pintu pemasukan saluran pengelak ditambah tinggi jagaan yang diperlukan untuk keamanan cofferdam tersebut

Tabel 2 Standar Ruang Bebas Menurut JANCOLD

\begin{tabular}{|c|c|c|c|}
\hline No & $\begin{array}{c}\text { Tinggi } \\
\text { Bendunga } \\
\mathrm{n}(\mathrm{m})\end{array}$ & $\begin{array}{c}\text { Bendunga } \\
\mathrm{n} \text { Beton }\end{array}$ & $\begin{array}{c}\text { Bendunga } \\
\mathrm{n} \text { Urugan }\end{array}$ \\
\hline 1 & $<50$ & $1 \mathrm{~m}$ & $2 \mathrm{~m}$ \\
\hline 2 & $50-100$ & $2 \mathrm{~m}$ & $3 \mathrm{~m}$ \\
\hline 3 & $>100$ & $2,5 \mathrm{~m}$ & $3,5 \mathrm{~m}$ \\
\hline
\end{tabular}

Sumber : Soedibyo (1993)

Tinggi Cofferdam $(\mathrm{H})=$ tinggi maksimum muka air + tinggi jagaan

$=13,6+1$

$=14,6 \sim 15 \mathrm{~m}$

\section{Perhitungan Lebar Puncak Cofferdam}

Untuk memperoleh lebar minimum mercu bendungan, biasanya dihitung dengan rumus sebagai berikut (Sosrodarsono \& Takeda, 2016) :

$$
\begin{aligned}
B \quad & =3,6 \cdot H^{1 / 3}-3 \\
& =3,6 \cdot 15^{1 / 3}-3 \\
& =7 \mathrm{~m}
\end{aligned}
$$

Keterangan:

$B=$ lebar mercu $(\mathrm{m})$,

$H=$ tinggi $\operatorname{cofferdam}(\mathrm{m})$ 
Pada tubuh cofferdam urugan mempunyai kemiringan lereng tertentu, untuk perhitungan kemiringan lereng cofferdam bendungan kualu berdasarkan tabel 2.3 Kemiringan Lereng yang dianjurkan (kodoatie, 2002). Maka dengan inti lempung dan urugan menggunakan kerikil dan kerakal diperoleh kemiringan hulu $1: 1,5$ dan kemiringan hilir 1 : 1,25 .

\section{Material Tubuh Cofferdam}

Tanah ataupun tanah liat yang dipakai sebagai bahan timbunan lapisan kedap air ini haruslah memenuhi persyaratan utama untuk bahan kedap air yaitu :

- Koefisien filtrasi serta kekuatan bagi yang diinginkan.

- Tingkat deformasi yang rendah.

- Mudah pelaksanaan pemadatannya.

- Tidak mengandung zat-zat organis serta bahan mineral yang mudah terurai.



Gambar 5 Desain Cofferdam

Keterangan:

- Material inti : lempung (clay)

- Material Filter : Pasir (sand)

- Material tubuh cofferdam : Urugan batu (pecahan batu)

- Material rip rap : batu

\section{Terowongan Tapal Kuda}

Pada perencanaan konstruksi terowongan pengelak didesain dengan bentuk tapal kuda. Adapun kelebihan dari terowongan pengelak berbentuk tapal kuda adalah sebagai berikut:

1. Terowongan tapal kuda memiliki atap semi bulat dengan dinding dan dasar agak melengkung. Bentuk ini memberi keuntungan dasar yang lebih datar dan lebih lebar untuk memudahkan dalam pelaksanaan terowongan tanpa mengorbankan efisiensi hidrolik yang tetap sama seperti luas potongan melintang bentuk bulat.

2. Cocok digunakan pada kondisi batuan yang keras.

\section{Analisa Pembebanan}

Sepanjang terowongan pengelak memiliki 3 lokasi bor (BH 16, BH17, BH18). Dari ketiga hasil pemboran tersebut dianalisa untuk menentukan data batuan yang akan digunakan dalamperhitungan pembebanan.

Dari hasil analisa diperoleh data mekanika tanah yang paling buruk diantara 3 borehole yang ada yaitu $\mathrm{BH} 16$ dengan nilai RQD (rock quality designation) $70 \%$.

Kemudian untuk menentukan tinggi muatan berdasarkan klasifikasi tinggi muatan batuan (Hp) menurut terzaghi (Singh \& Goel, 2006), maka rumus untuk nilai RQD 30\% - 75\% digunakan $\mathrm{Hp}=(0,2-0,6)(\mathrm{B}+\mathrm{Ht})$. Dalam perhitungan dipilih penggunaan rumus $\mathrm{Hp}=0,5$ ( $\mathrm{B}+\mathrm{Ht})$.



Gambar 6 Desain Terowongan Pengelak Shape F

Perhitungan pembebanan pada terowongan dalam perencanaan ini adalah sebagai berikut:

1. Tekanan Batuan Vertikal

$\mathrm{qbv}=\gamma_{\text {batuan }} . \mathrm{Hp}$

Keterangan:

$\mathrm{Jp}=$ tinggi muatan

2. Tekanan batuan Horizontal

- Kondisi normal

$\mathrm{Pa} 1=\mathrm{Ka} \times \gamma_{\text {batuan }} \mathrm{X}(\mathrm{hp}+\mathrm{ht})$

$\mathrm{Pa} 2=\mathrm{Ka} \times \gamma_{\text {batuan }} \mathrm{x} \mathrm{h}_{\mathrm{t}}$

- Kondisi gempa

$\mathrm{Pa} 1=$ Kae $\mathrm{x} \gamma_{\text {batuan }} \mathrm{x}\left(\mathrm{hp}+\mathrm{h}_{\mathrm{t}}\right)$

$\mathrm{Pa} 2=$ Kae $\mathrm{x} \gamma_{\text {batuan }} \times \mathrm{h}_{t}$

3. Tekanan Air Horizontal

Pwh $=\gamma w .(\mathrm{Hw}+\mathrm{Ht})$

Keterangan:

$\gamma \mathrm{w}=$ berat jenis air

$\mathrm{Hw}=$ tinggi air di atas terowongan

$\mathrm{Ht}=$ tinggi terowongan

4. Tekanan Air Vertikal

$q w v=\gamma w . H w$ 
Keterangan:

$\gamma \mathrm{w}=$ berat jenis air

$\mathrm{Hw}=$ tinggi air di atas terowongan

5. Berat Akibat Konstuksi Terowongan

$\mathrm{q}=\gamma \mathrm{c} . \mathrm{t}$

Keterangan:

$\gamma \mathrm{c}=$ berat isi beton $\left(\mathrm{t} . \mathrm{m}^{-3}\right)$

$\mathrm{t}=$ tebal terowongan $(\mathrm{m})$

6. Tekanan Air dalam Terowongan

$\mathrm{P}=\gamma \mathrm{w} . \mathrm{g} . \mathrm{h}$.

Keterangan:

$\gamma \mathrm{W}=$ berat jenis air

$\mathrm{h}=$ diameter dalam terowongan

7. Tekanan uplift

$\mathrm{P}=\gamma \mathrm{w}$. Ht

Keterangan:

$\gamma \mathrm{w}=$ berat jenis air

$\mathrm{Ht}=$ tinggi terowongan

8. Beban Kendaraan

Beban kendaraan berpengaruh pada terowongan apabila terowongan berada pada kedalaman kurang dari $10 \mathrm{ft}$ atau sekitar $3 \mathrm{~m}$. karena lokasi terowongan berada $>10 \mathrm{ft}$, maka beban kendaraan tidak diperhitungkan pada perencanaan. (Doyle Drive, 2009).

\section{Kombinasi Pembebanan}

Kondisi 1 : Kasus pembebanan pada saat setelah selesai dibangun (just after completion)

1. Kondisi setelah dibangun (Just After Completion), beban yang bekerja antara lain

- Berat sendiri tunnel (selfweight)

- Beban tanah di atas terowong (external rock load)

- Tekanan tanah aktif di samping terowongan

- Reaksi akibat beban vertikal

2. Kondisi setelah dibangun (Just After Completion - gempa, beban yang bekerja antara lain :

- Berat sendiri tunnel (selfweight)

- Beban tanah di atas terowong (external rock load)

- Tekanan tanah aktif di samping terowongan

- Reaksi akibat beban vertikal

Kondisi 2 : Berfungsi atau beroperasi sebagai terowong pengelak, kondisi air penuh

1. Berfungsi atau beroperasi sebagai terowong pengelak dan kondisi air penuh, beban yang bekerja antara lain :

- Berat sendiri terowong (selfweight)
- Beban tanah di atas terowong (external rock load)

- Tekanan air tanah (external water pressure)

- Tekanan tanah aktif di samping terowongan

- Gaya angkat (uplift pressure)

- Reaksi akibat beban vertikal

- Tekanan air dari dalam terowongan (internal water pressure)

2. Berfungsi atau beroperasi sebagai terowong pengelak dan kondisi air penuh - gempa, beban yang bekerja antara lain :

- Berat sendiri tunnel (selfweight)

- Beban tanah di atas terowong (external rock load)

- Tekanan air tanah (external water pressure)

- Tekanan tanah aktif di samping terowongan

- Gaya angkat (uplift pressure)

- Reaksi akibat beban vertikal

- Tekanan air dari dalam terowongan (internal water pressure)

\section{Perhitungan Momen, Lintang, dan Normal}

Perhitungan momen, lintang, dan normal pada perencanaan terowongan pengelak dilakukan dengan 2 metode yaitu metode Beggs Deformation Analysis of Single Barel Conduit (Philips \& Allen, 1986) dan metode menggunakan Software Staad Pro. Dari hasil perhitungan akan didapatkan momen maksimum yang kemudian akan digunakan untuk mendesain tulangan pada terowongan.

Tabel 3 Momen Maksimum Metode Beggs

\begin{tabular}{|c|l|c|c|c|}
\hline \multirow{2}{*}{ No } & \multirow{2}{*}{ Kondisi } & Momen & Normal & Lintang \\
\cline { 3 - 5 } & & (ton.m) & (ton) & (ton) \\
\hline 1 & Setelah Dibangun & -163.226 & 258.4903 & 112.4012 \\
\hline 2 & Setelah Dibangun (gempa) & -199.300 & 288.8785 & 133.2071 \\
\hline 3 & Terowongan Beroperasi & 241.512 & 298.6594 & 32.50982 \\
\hline 4 & Terowongan Beroperasi (gempa) & 212.083 & 299.6878 & 24.15053 \\
\hline & Maks & 241.512 & 299.6878 & 133.2071 \\
\hline
\end{tabular}




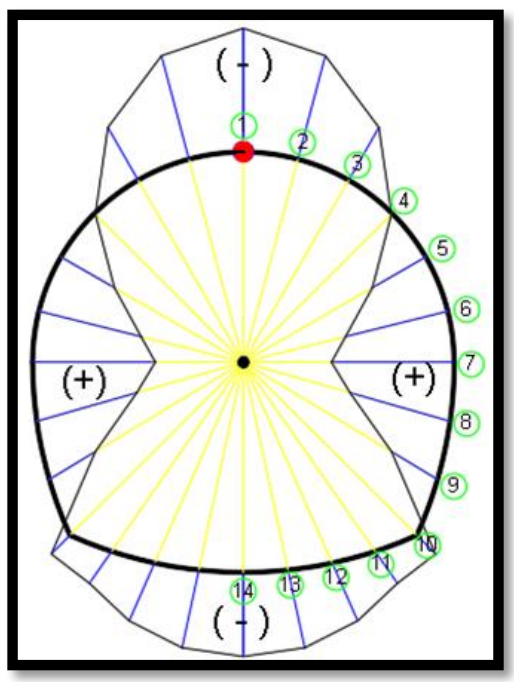

Gambar 7 Bidang Momen Kondisi Setelah Dibangun Metode Beggs

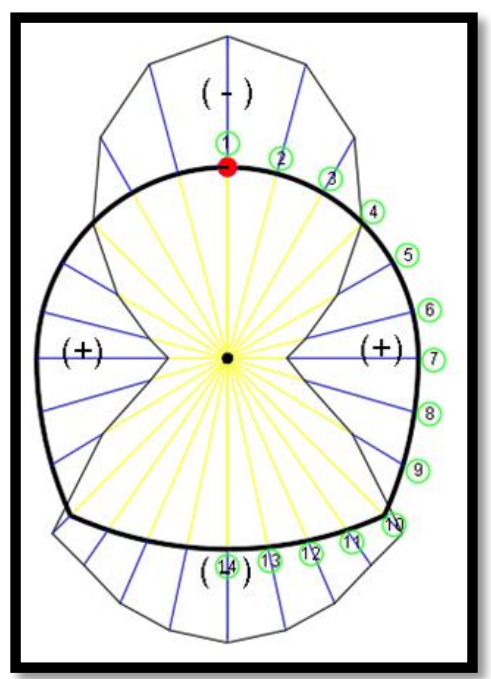

Gambar 8 Bidang Momen Kondisi Setelah Dibangun (gempa) Metode Beggs

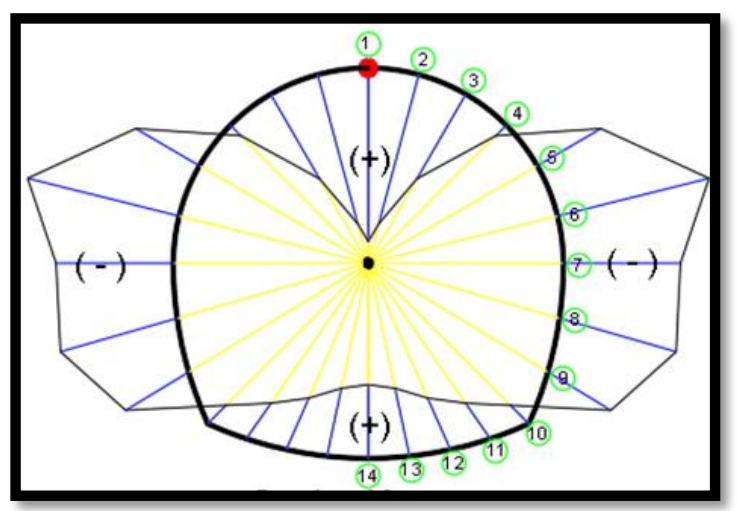

Gambar 9 Bidang Momen Kondisi Setelah Beroperasi Metode Beggs

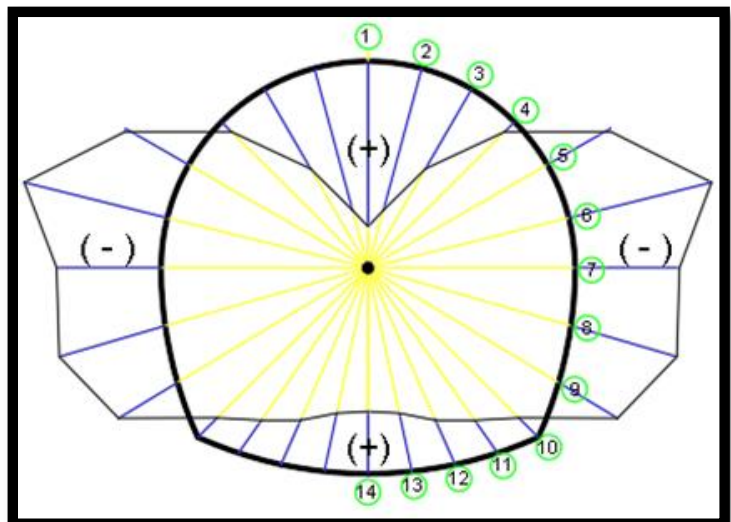

Gambar 10 Bidang Momen Kondisi Setelah Beroperasi (2019) Metode Beggs

Tabel 4 Momen Maksimum Searah Sumbu x metode Staad Pro

\begin{tabular}{lllll}
\hline No & Keterangan & No Plat & Kondisi & Momen Max (ton.m) \\
\hline 1 & Plat bagian bawah & 64 & $\begin{array}{l}\text { Setelah Beroperasi } \\
\text { (gempa) }\end{array}$ \\
2 & Plat bagian atas & 66 & $\begin{array}{l}\text { Setelah Beroperasi } \\
\text { (gempa) }\end{array}$ & 4,477 \\
\hline
\end{tabular}



Gambar 11 Momen Searah Sumbu x Metode Staad Pro

\section{Analisa Pemilihan Momen Maksimum}

Dari hasil perhitungan dilakukan analisa terhadap masing-masing metode. Terdapat 3 aspek yang akan dianalisa:

1. Tinjauan

- Metode beggs

Perhitungan menggunakan metode Beggs ditinjau secara 2D 
- Metode Staad Pro

Perhitungan menggunakan Staad Pro ditinjau secara 3D

Hasil perhitungan secara 2D menunjukan hasil momen maksimum yang jauh lebih besar apabila dibandingkan dengan perhitungan secara 3D. Hal ini dapat diakibatkan oleh tinjauan secara 3D perhitungan lebih detail dari segi input pembebanan. Input pembebanan pada perhitungan secara 3D dilakukan mulai dari bentuk dari diagram tekanan dan jenis pembebanannya.

2. Tekanan Batuan Horizontal

- $\quad$ Metode Beggs

Pada metode Beggs perhitungan tekanan batuan horizontal digunakan tekanan paling maksimum yang terjadi. Gaya dianggap seragam di samping terowongan.

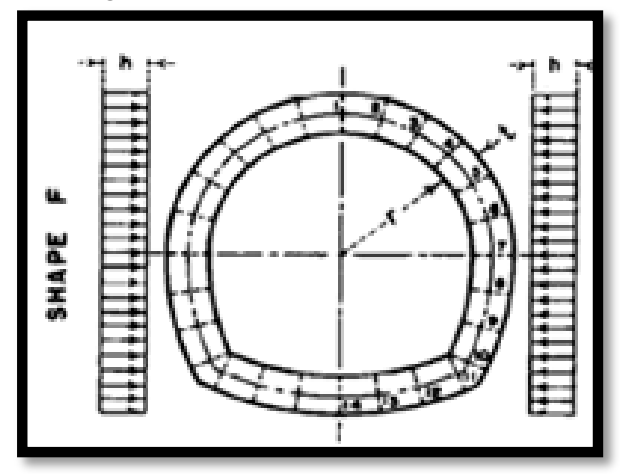

Gambar 12 Diagram Tekanan Batuan Horizontal Metode Beggs

Sumber: Philips \& Allen (1986)

- $\quad$ Metode Staad Pro

Diagram gaya pada Software Staad Pro berbentuk trapezium yang dapat dikatakan lebih mewakili hasil dari perhitungan pembebanan tekanan batuan horizontal yang diagramnya berbentuk trapezium

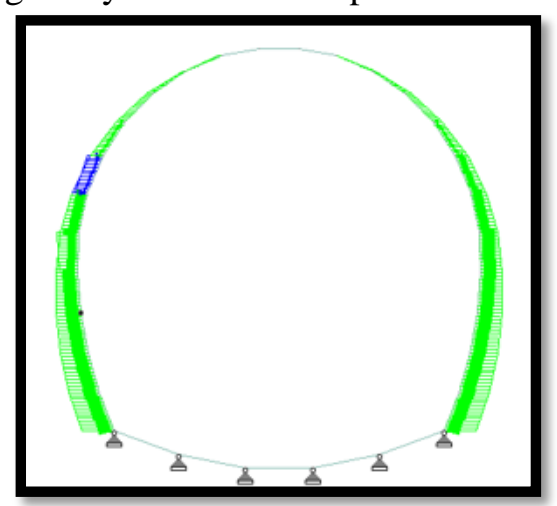

Gambar 13 Diagram Tekanan Batuan Horizontal Metode Staad Pro
Diagram tekanan batuan horizontal yang terjadi pada terowongan yang sesuai pada perhitungan pembebanan ialah berbentuk trapesium disamping teowongan. Diagram pembebanannya dapat dilihat seperti gambar di bawah ini:

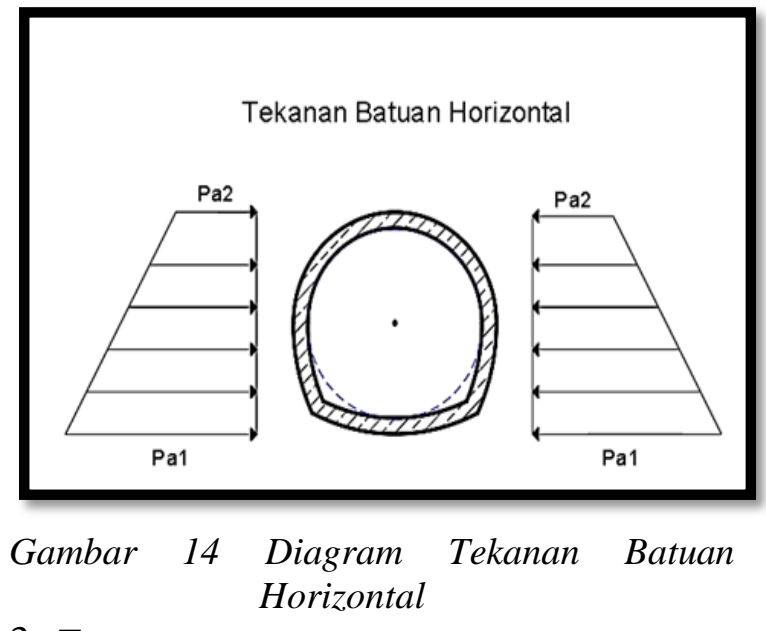

3. Tumpuan

- $\quad$ Metode Beggs

Pada Metode Beggs tumpuan tidak diperhitungkan, gaya vertikal diasumsikan sudah dapat mewakili kondisi tumpuan.

- $\quad$ Metode Staad Pro

Pada Staad Pro tumpuan diasumsikan sebagai sendi hal ini dikarenakan untuk tumpuan roll tidak mungkin digunakan pada terowongan pengelak dan tumpuan jepit biasanya digunakan pada struktur yang langsung terhubung dengan tanah (seperti perhitungan pondasi dll)

Perbedaan pada tumpuan ini dimungkinkan merupakan penyebab terjadinya perbedaan letak dari momen maksimum pada terowongan. Pada metode Beggs momen maksimum terletak di atas terowongan (pada point 1). Sedangkan pada metode Staad Pro titik maksimum berada di dekat kedua tumpuan. Hasil Perhitungan dari momen metode Beggs merupakan momen searah dengan sumbu $\mathrm{x}$ pada software Staad Pro.

Dari hasil analisa, diputuskan digunakan momen maksimum hasil perhitungan Staad Pro untuk perhitungan penulangan.

\section{Penulangan pada Terowongan}

Karena beton kuat terhadap tekan dan lemah terhadap tarik, maka baja diperlukan untuk menahan tarik pada konstruksi terowongan. 


\section{Perhitungan Tulangan Utama}

Perhitungan dilakukan dengan konsep plat. Plat yang digunakan setebal $75 \mathrm{~cm}$. rumus yang digunakan dalam perencanaan adalah:

Batas rasio tulangan maksimum balok adalah (setiawan, 2013) :

$$
\begin{aligned}
& \rho_{\text {min }}=\frac{1,4}{f y} \\
& \rho_{\max } \quad=0,75 \cdot \frac{\beta . \mathrm{fc}^{\prime}}{f y} \cdot \beta \cdot \frac{600}{600+f y} . \\
& \mathrm{Rn} \quad=\text { Mx } \max \cdot 10^{6} / \Phi \cdot \mathrm{b} \cdot \mathrm{d}^{2} \text {. } \\
& \omega \quad=0,85 .\left(1-\sqrt{1-\frac{2,353 \cdot R n}{f^{\prime} c}} \ldots \ldots . .\right. \\
& \rho \quad=\omega \cdot \frac{f^{\prime} c}{f y}
\end{aligned}
$$

$$
\text { As } \quad=\rho . b \cdot d
$$

Memakai D22 membutuhkan jumlah = As / 379,940

Jarak bersih antar tulangan:

$(\mathrm{Sn})=\mathrm{b} /(\mathrm{as} / 379,940)$

Syarat harus $\geq$ as perlu

As perlu $=2422 \mathrm{~mm}^{2}$

As hitung $=2532 \mathrm{~mm}^{2} \geq$ As perlu (memenuhi)

Dari hasil perhitungan dipilih menggunakan D22 - 150 .

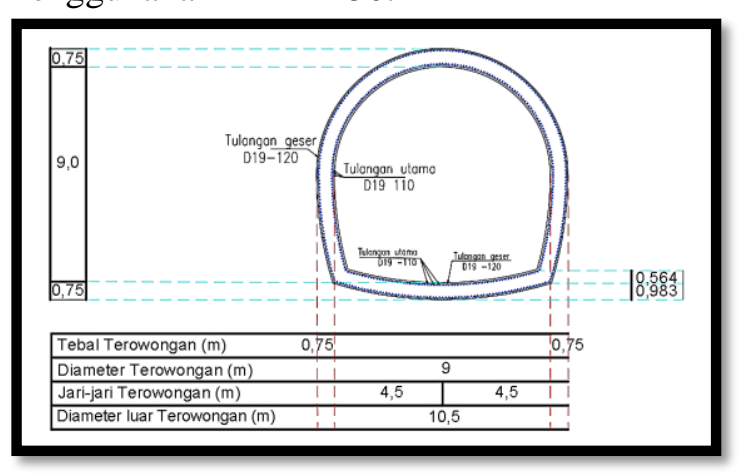

Gambar 15 Sketsa Penulangan pada Terowongan

\section{Perhitungan Tulangan Bagi}

Perhitungan tulangan bagi menggunakan momen maksimum searah sumbu $y$, rekapitulasi perhitungan momen maksimum tersebut di bawah ini:

Tabel 5 Momen searah sumbu y (metode Staad \begin{tabular}{llll} 
& Pro) & & \\
\hline No & Keterangan & No Plat Kondisi & Momen Max (ton.m)
\end{tabular}

\begin{tabular}{rrrrr}
\hline 1 & Plat bagian bawah & 64 & $\begin{array}{l}\text { Setelah dibangun 28,265 } \\
\text { (gempa) }\end{array}$ \\
2 & Plat bagian atas & 89 & $\begin{array}{l}\text { Setelah dibangun 25,135 } \\
\text { (gempa) }\end{array}$ \\
\hline & Dari & hasil & perhitungan dipilih
\end{tabular}

\section{Alternatif Desain Terowongan Pengelak}

Analisa alternatif desain terowongan pengelak bertujuan untuk mencari desain yang lebih ekonomis dari desain sebelumnya (desain sebelumnya menggunakan plat setebal $75 \mathrm{~cm}$ ) kemudian dilakukan analisa perhitungan momen maksimum menggunakan software Staad Pro. Hal ini merupakan salah satu kelebihan software Staad Pro jika dibandingkan dengan metode Beggs. Jika dalam perhitungan sebelumnya, terowongan menggunakan desain paling ekonomis berdasarkan rekomendasi dari metode Beggs $(\mathrm{t}=\mathrm{r} / 6)$.

Kemudian dilakukan percobaan menggunakan mulai dari tebal plat $30 \mathrm{~cm}$. kemudian akhirnya didapat kesimpulan digunakan desain terowongan pengelak dengan

\begin{tabular}{|c|c|}
\hline & $\mathrm{N} / \mathrm{Pl}$ \\
\hline
\end{tabular}
tebal plat $50 \mathrm{~cm}$. Rekapitulasi hasil

\begin{tabular}{|c|c|c|}
\hline 1 Plat bagiman baxah & 64 & Seteldu Beroperasi 63,097 \\
\hline 2. Plat bagiand atas & 66 & Seteldar Betoverasis 45,114 \\
\hline
\end{tabular}
perhitungannya dapat dilihat pada tabel di bawah ini:

Tabel 6 Momen maksimum searah sumbu $\mathrm{x}$

\begin{tabular}{|c|c|c|}
\hline No Keterangan & No Plat & Momen Max (tonum) \\
\hline $1 \quad$ Plat baggian baxwah & 64 & Setedel Beropetasin 26,743 \\
\hline 2 Plat tagianan atas & 66 & Setedel Beroperasi 17,318 \\
\hline
\end{tabular}
(Mx) untuk Tebal Plat $50 \mathrm{~cm}$

Tabel 7 Momen maksimum searah sumbu y (My) untuk Tebal Plat $50 \mathrm{~cm}$

\section{Tulangan utama}

$$
\begin{aligned}
\rho_{\min } & =\frac{1,4}{f y} \\
& =0,0035 \\
\rho_{\max } \quad & 0,75 \cdot \frac{\beta \cdot \mathrm{fc} \prime}{f y} \cdot \beta \cdot \frac{600}{600+f y} \\
& =0,0207 \\
\mathrm{Rn} \quad & \mathrm{Mx} \cdot 10^{6} / \Phi \cdot \mathrm{b} \cdot \mathrm{d}^{2} \\
\omega \quad & =3,317 \\
& =0,85 \cdot\left(1-\sqrt{1-\frac{2,353 \cdot R n}{f^{\prime c}}}\right) \\
& =0,119 \\
& =\omega \cdot \frac{f \prime c}{f y} \\
& =0,008917
\end{aligned}
$$


(karena $\rho$ lebih besar dari $\rho$ min, maka digunakan $\rho$ )

$$
\text { As } \quad \begin{aligned}
& =\rho \cdot b \cdot d \\
& =0,0089 \cdot 1000 \cdot 375 \\
& =3566 \mathrm{~mm}^{2}
\end{aligned}
$$

Memakai D25 membutuhkan jumlah = As $/$ 490,625

Jarak bersih antar tulangan $(\mathrm{Sn})=$ $\mathrm{b} /($ as/490,625 $)=137,556 \mathrm{~mm} \sim 130 \mathrm{~mm}$

As $\quad=490,625 . \mathrm{b} / \mathrm{Sn}$ $=3774 \mathrm{~mm}^{2} \geq$ As perlu (memenuhi)

Dari hasil perhitungan digunakan D25 - 90

\section{Tulangan bagi}

As perlu $=3566 \mathrm{~mm}^{2}$

Penampang D17 $=1 / 4 \cdot 3,14.17^{2}=226,98 \mathrm{~mm}^{2}$ Dilakukan percobaan menggunakan D17 didapatkan hasil jarak antar tulangan $140 \mathrm{~mm}$ As Hitung $\quad=1435 \mathrm{~mm}^{2} \geq$ As perlu (memenuhi)

Jadi digunakan D17 - 140

\section{KESIMPULAN}

Berdasarkan perencanaan yang telah dilakukan, maka dapat ditarik kesimpulan sebagai berikut:

1. Terowongan pengelak Bendungan Kualu direncanakan berbentuk tapal kuda shape $F$, dengan debit rancangan kala ulang 25 tahun sebesar 709,331 m³/dt. Sehingga didapatkan diameter terowongan pengelak sebesar $9 \mathrm{~m}$ dan dari analisa penelusuran banjir didapatkan tinggi air maksimum pada elevasi $+710,383$ (tinggi air maksimum $=$ $10,883 \mathrm{~m})$.

2. Berdasarkan hasil perhitungan, maka didapatkan hasil dari pembebanan yang bekerja pada terowongan yaitu sebagai berikut

- Tekanan Batuan Vertikal $=22,425$ ton $/ \mathrm{m}$

- Tekanan Batuan Horizontal (kondisi Normal)

Pa1 $=33,83 \mathrm{t} / \mathrm{m}$

$\mathrm{Pa} 2=17,543 \mathrm{t} / \mathrm{m}$

- Tekanan Batuan Horizontal (kondisi gempa)

$\mathrm{Pa} 1=39,69 \mathrm{t} / \mathrm{m}$

$\mathrm{Pa} 2=19,394 \mathrm{t} / \mathrm{m}$

- $\quad$ Tekanan Air Horizontal = 10,95 ton $/ \mathrm{m}$

- $\quad$ Beban Air Vertikal = 41,625 ton $/ \mathrm{m}$

- Beban Akibat Berat Sendiri = 1,8 ton $/ \mathrm{m}$

- Tekanan Air dalam Terowongan = $88,29 \mathrm{t} / \mathrm{m}$

- Tekanan uplift $=10,5$ ton $/ \mathrm{m}$
3. Berdasarkan kondisi pembebanan yang bekerja pada terowongan, maka dihitung momen maksimum menggunakan 2 cara yaitu tabel Beggs Deformation Analysis of Single Barel Conduit dan software Staad Pro. Dari hasil analisa didapatkan kesimpulan

\section{Hasil Perhitungan Metode Staad Pro}

Dari hasil analisa, diputuskan penggunaan hasil perhitungan momen menggunakan software staad pro yang pertimbangannya adalah sebagai berikut:

- Staad Pro melakukan analisa 3d yang berarti perhitungan pembebanan yang terjadi pada terowongan lebih mendetail, karena pembebanan searah sumbu z (memanjang terowongan) juga diperhitungkan.

- Diagram gaya yang ada pada staad pro lebih mewakili hasil dari perhitungan, karena pada staad pro input jenis pembebanan dibedakan sesuai dengan jenis dari beban tersebut, seperti beban hidup, beban mati, beban hidrostatik, dan beban tanah.

- Jenis struktur yang di inputkan pada software staad pro lebih detail seperti struktur tersebut terbuat dari plat, balok, kolom, dan lain sebagainya.

- Staad Pro dapat melakukan perhitungan momen dengan ketebalan plat yang lebih ekonomis, sedangkan pada tabel beggs dibatasi dengan desain paling ekonomis adalah $\mathrm{t}=\mathrm{r} / 6$, hal ini penting karena untuk perhitungan alternatif desain terowongan pengelak akan dicari penampang dengan ketebalan plat paling minimum yang dapat digunakan.

\section{Hasil Perhitungan Metode Beggs}

Dari analisa perhitungan momen yang dilakukan oleh tabel beggs menggunakan konsep 2 dimensi maka hasil dari momen maksimum didapatkan jauh lebih besar jika dibandingkan dengan hasil perhitungan menggunakan software Staad Pro. Hal ini dikarenakan tinjauan secara tiga dimensi (menggunakan Staad Pro) dimungkinkan lebih dapat mewakili beban yang ada. Sehingga untuk membuat konstruksi aman, maka tinjauan secara 2 dimensi dapat menghasilkan nilai yang besar. Kemudian sebuah perbedaan pada metode beggs jika dibandingkan dengan staad pro yaitu pada metode beggs tumpuan tidak diper- 
hitungkan, tumpuan diasumsikan sebagai gaya vertikal atau menjadi sebuah beban. Karena alasan tersebut, dimungkinkan terjadinya perbedaan titik momen maksimum Antara metode Beggs dan metode Staad Pro. Sehingga diputuskan penggunaan momen metode Staad Pro karena Staad Pro lebih mewakili dengan kondisi yang ada.

Perhitungan penulangan pada terowongan pengelak Bendungan Kualu diperoleh hasil sebagai berikut:

Menggunakan software Staad Pro

- Diameter tulangan utama $=$ D22 -150

- Diameter tulangan bagi= D19-120

Selanjutnya dilakukan alternatif desain pada terowongan pengelak yang tujuannya untuk mencari desain yang paling ekonomis, dilakukan analisa tambahan menggunakan staad pro dengan desain plat yang lebih kecil dari desain rencana awal yang berpedoman pada tabel beggs (desain paling ekonomis yang dianjurkan oleh tabel beggs adalah $\mathrm{t}=\mathrm{r} / 6=0,75$ $\mathrm{m})$, kemudian dilakukan desain plat yang lebih ekonomis, dan didapatkan tebal plat $=0,5 \mathrm{~m}$. Dari hasil perhitungan penulangan, didapatkan:

- Diameter tulangan utama atas = D25-130

- Diameter tulangan utama bawah $=$ D25 -90

- Diameter tulangan bagi = D16 -140.

\section{DAFTAR PUSTAKA}

Bureau of Reclamation. (1987). Design of small Dams. Water Resources Technical Publication. Washington

Chow, Ven Te. (1992). Hidrolika Saluran Terbuka. Jakarta: Erlangga.

Doyle Drive Replacement Project. (2009). Structural Desaign Citeria for Cut and Cover tunnels \& Non Standard Retaining Walls. Brisbane

Kodoatie, Robert J. (2002). Rekayasa Manajemen Banjir Kota. Yogyakarta: Andi

Loebis, Joerson. (1984). Banjir Rencana untuk Bangunan Air. Jakarta: Badan Penerbit Pekerjaan Umum.

Philips, H. B., \& I.E. Allen. (1986). Beegs Deformeter Stress Analysis of Single Barrel Conduits. Colorado: United States Bureau of Reclamation.

Setiawan, Agus. (2016). Perencanaan Struktur Betoon Bertulang. Jakarta: Erlangga.

Singh, Bhawani., \& Rajnish. K. Goel. (2006). Tunneling in Weak Rock. Bungalore: Elsevier.

Soedibyo. (1993). Teknik Bendungan. Jakarta : Pradnya Paramita.

Sosrodarsono, Suryo., \& Kensaku Takeda. (2016). Bendungan Tipe Urugan. Jakarta: Balai Pustaka. 
